Portland State University

PDXScholar

Spring 7-24-2013

\title{
Measuring the Effects of Environmental Certification on Residential Property Values - Evidence from Green Condominiums in Portland, U.S.
}

Xi Yang

Portland State University

Follow this and additional works at: https://pdxscholar.library.pdx.edu/open_access_etds

Part of the Environmental Design Commons, Urban, Community and Regional Planning Commons, and the Urban Studies and Planning Commons

Let us know how access to this document benefits you.

\section{Recommended Citation}

Yang, Xi, "Measuring the Effects of Environmental Certification on Residential Property Values - Evidence from Green Condominiums in Portland, U.S." (2013). Dissertations and Theses. Paper 1113.

https://doi.org/10.15760/etd.1113

This Thesis is brought to you for free and open access. It has been accepted for inclusion in Dissertations and Theses by an authorized administrator of PDXScholar. Please contact us if we can make this document more accessible: pdxscholar@pdx.edu. 
Measuring the Effects of Environmental Certification on Residential Property Values

- Evidence from Green Condominiums in Portland, U.S.

by

Xi Yang

A thesis submitted in partial fulfillment of the requirements for the degree of

\author{
Master of Urban Studies \\ in \\ Urban Studies \\ Thesis Committee: \\ Ethan Seltzer, Chair \\ James Strathman \\ Loren Lutzenhiser
}

Portland State University

2013 
(C) 2013 Xi Yang 


\begin{abstract}
Green building, as an environmentally responsible and resource-efficient product, has emerged in recent decades. Along with the growing interest in green building design and operating practices, a number of green building certification standards and rating systems have been developed by different organizations worldwide. Those rating systems allow government regulators, building professionals, and consumers to embrace green building with confidence. Many recent studies find that LEED and Energy Star certified commercial buildings gain significant rental and sales price premiums and have higher occupancy rates. However, little research has been conducted to measure the market value of certified multi-family residential buildings, for instance, green condominiums. This study investigates the price effects of LEED certification on condominium real estate assets in a local housing market, in this case Portland, Oregon. The overall dataset is developed by combining information from Metro’s Regional Land Information System (RLIS) and LEED certifications by the U.S. Green Building Council (USGBC). A hedonic pricing model is employed to measure the effects of certification levels on sales prices. The model results indicate that, compared to non-certified condominiums in Portland, green certified properties have a 5.8 percent sales price premium on average. The result of this study confirms that LEED condominiums exhibit higher sales prices controlling for location- and property-specific factors.
\end{abstract}

Key words: Green Building; Condominium Market; LEED; Hedonic Pricing Model 


\section{ACKNOWLEDGEMENTS}

I would like to express my deep gratitude to my advisor: Prof. Ethan Seltzer, and my thesis committee members: Prof. James Strathman and Loren Lutzenhiser, for their patient guidance, enthusiastic encouragement, constructive suggestions and useful critiques of this research work. I would like to express my very great appreciation to Prof. Strathman for his help in guiding my research direction with existing data, and his assistance with the methodological and data analysis used in this research. I would like to offer my sincerely thank to Prof. Seltzer, for his advice during the planning and development of this work and assistance in keep my progress on schedule. My grateful thanks are also extended to Prof. Lutzenhiser for his insightful questions and advices for this research work.

I would also like to offer my special thanks to Julia Freybote from PSU Center for Real Estate, for her warmly advice on my data collection; my friend Liang Ma, for his help consulting the regression analysis; my friend Li'an Zhu, for his patient text proofreading.

Finally, I wish to thank my parents and my roommates for their support and encouragement throughout my study. 


\section{TABLE OF CONTENTS}

ACSTRACT

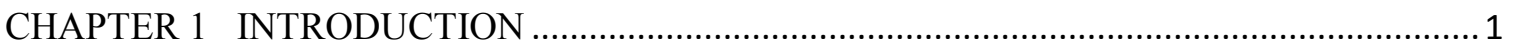

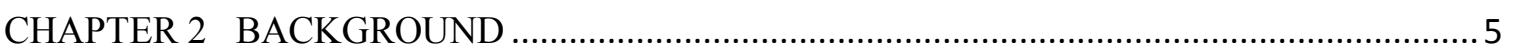

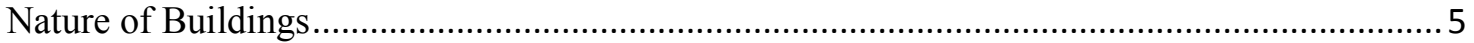

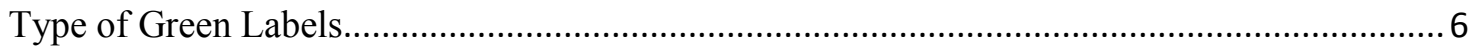

Factors for Being Green-Certified Buildings.....................................................................

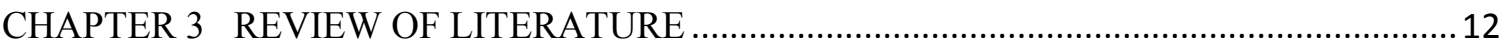

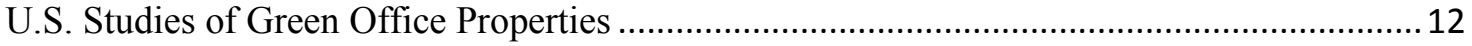

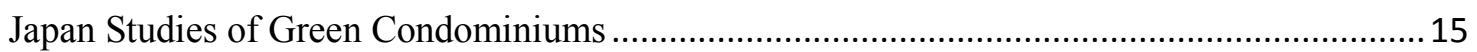

CHAPTER 4 STATEMENT OF PURPOSE ...................................................................... 18

CHAPTER 5 DATA AND METHODOLOGY .................................................................2

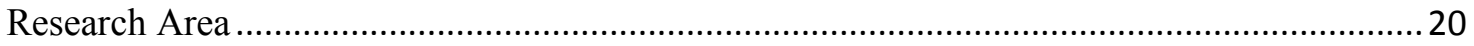

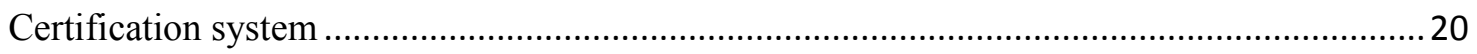

LEED Certification and Related Policies........................................................................22

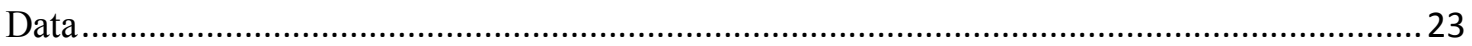

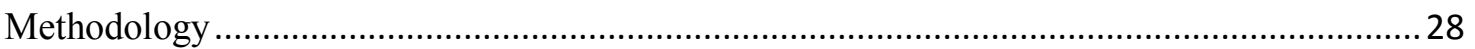

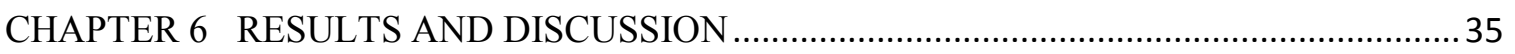

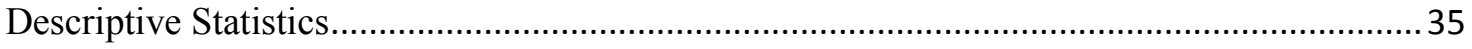

Hedonic Regression Results and the Price Premium .............................................................36

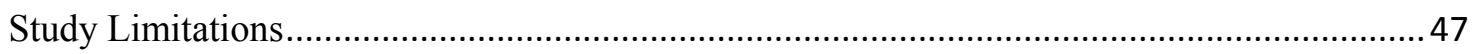

CHAPTER 7 CONCLUSION AND POLICY IMPLICATIONS .............................................. 49

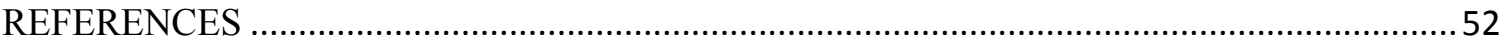




\section{LIST OF TABLES}

TABLE 1 Summary of U.S. Green Office Value Studies

TABLE 2 LEED Rating Systems and Versions

TABLE 3 LEED for New Construction v 2.2 Project Categories

TABLE 4 LEED for Neighborhood Development Pilot Project Categories

TABLE 5 Portland Green Condominium Buildings

TABLE 6 Variable Summary Statistics

TABLE 7 Descriptive Statistics of Overall Sample with LEED-NC Samples

TABLE 8 Descriptive Statistics of Overall Sample with LEED-ND Samples

TABLE 9 Comparison of LEED-NC Gold Condominium Sales Prices

TABLE 10 Regression Results of LEED-NC Certification and Sales Prices

TABLE 11 Regression Results of LEED-ND Certification and Sales Prices 


\section{LIST OF FIGURES}

FIGURE 1 One Mile Buffer Map

FIGURE 2 Submarkets Map

FIGURE 3 Distribution of Sale Price

FIGURE 4 Distribution of Log Transformation of Sale Price 


\section{CHAPTER 1 INTRODUCTION}

The green building movement in the U.S. originated from the need and desire for more energy efficient and environmentally friendly construction practices ${ }^{1}$. Green building has emerged as an environmentally responsible and resource-efficient practice, and has been rapidly developed over the past decade. Green design, construction, operation, and maintenance technologies can consume significantly less energy and resources. Along with the growing interest in green building concepts and practices, a number of green building certification standards and rating systems have been developed by different organizations worldwide. The environmental certification programs provide guidelines for the design, construction, and operation of green buildings, as well as a standard to assess the environmental performance of buildings over their life cycles. The ecocertification systems provide signals that facilitate the matching of 'eco-customers' to the products carrying the desired characteristics (Fuerst, 2009), and allow government regulators, building professionals, and consumers to embrace green building with confidence.

Although it is touted that green-certified buildings have various economic, social and environmental benefits, in reality, there remain doubts about whether and how well their 'greenness' is 'priced' or 'recognized' in the market. Much empirical evidence (Kok et al., 2011; Fuerst, 2009; Newsham et al., 2009; Bartlett \& Howard, 2000) of the environmental performance of green buildings, focusing on the response of the voluntary real estate market either in technical or social aspects. Many remain skeptical, however,

1 Green Building from Wikipedia 
about the economic value of green buildings, and a thorough analysis has yet to be conducted to evaluate whether green buildings can realize profit increases commensurate with the additional investment required at design and construction (Shimizu, 2010). Several recent studies (Fuerst \& McAllister, 2009 \& 2011; Eichholtz et al., 2009 \& 2010; Wiley et al., 2010; Pivo \& Fisher, 2010; Miller et al., 2008 \& 2009; Dermisi, 2009) exploring the impact of green labels on commercial property values confirm that customers are willing to pay extra money on rental and sales price for certified products. A majority of these studies have been conducted to examine the effect of the U.S. Green Building Council's Leadership in Energy and Environmental Design (LEED) System and the U.S. Environmental Protection Agency's Energy Star system on commercial property market. For example, Eichholtz et al (2010) identified 10,000 green and conventional buildings, and related contract rents, effective rents and sales price to a set of objective hedonic characteristics of buildings, holding constant the locational characteristics of properties. They found that buildings with a 'green rating' command rental rates that are roughly 3 percent higher per square foot than identical 'unrated' buildings, controlling for the quality and the specific location of office buildings. Premiums in effective rents are about 7 percent. Sales price premiums are even higher at about 16 percent. From the extant literature, a consensus is emerging that certified commercial buildings in the United States carry a rental and sales price premium both on theoretical and empirical grounds (Fuerst, 2009).

Housing serves as an asset as well as a durable consumption good (Yoshida, 2008). Due to the financial crisis and subsequent recession in 2007-2008, the U.S. housing market 
suffered a great deal. Housing prices decreased by $1 / 5$ to $1 / 3$ from 2007-08 housing prices. With the economic recovery that began in mid-2009 (Elwell, 2013), the housing market is buzzing again. Green housing has become a growing part of the market. Unlike the commercial real estate sector that has received considerable attention, only little research (Yoshida \& Sugiura, 2012; Yoshida \& Shimizu, 2010) has been conducted to measure the effects of voluntary eco-labeling on multi-family residential property values, for instance, green condominium residential properties. This research takes a first step towards answering the question, "how do eco-certification systems work in the housing market?'

This study investigates the capitalization effects of LEED-certification on the condominium market in Portland, Oregon. The data for this study are drawn from Portland Metro's Regional Land Information System (RLIS) and U.S. Green Building Council (USGBC). RLIS is a geographic information system maintained by Metro, the regional government in the Portland Metropolitan Area, provides information on property transactions, and renews the data every three months. USGBC certifies green building projects through its Leadership in Energy and Environmental Design (LEED) system. Only properties transacted between 2009 and March 2012 are included in the analysis to avoid the huge impact of the outbreak of the financial crisis. A hedonic Pricing Model is employed to measure the effect of certification levels on sales price controlling for property, location, neighborhood, time, and green characteristics. The analysis includes data on 691 LEED certified condos and 1110 non-LEED certified condos located within one mile of the certified condos. The model results indicate that, compared to non- 
certified condominiums in Portland, LEED-certified condominiums command a 5.8 percent price premium.

This paper is organized as follows. Chapter 2 provides background information on the nature of buildings, green building label systems, and the factors for being an eco-labeled building. This is followed by Chapter 3, a review of related literature which analyzes the price effects of environmental certification for commercial or residential properties in the real estate market. Chapter 4 identifies the research questions for this study and identifies two research hypotheses. Chapter 5 presents the empirical analysis, outlines the data and methodology applied in the study followed by Chapter 6 a discussion of the results and the limitation of this research. Chapter 7 concludes the study and suggests its policy implications. 


\section{CHAPTER 2 BACKGROUND}

\section{Nature of Buildings}

The built environment is designed to serve human needs, but it can also have significant negative impacts on the natural environment and on human health and performance. In the U.S., buildings account for 41 percent of total energy use ${ }^{2}$ and 73 percent of electricity consumption ${ }^{3}$. Buildings are also one of the largest consumers of materials and account for a significant portion of the greenhouse gas emissions. In the U.S., buildings account for 38 percent of all $\mathrm{CO}^{2}$ emissions ${ }^{4}$. Buildings use 13.6 percent of all potable water ${ }^{5}$ and 40 percent of raw materials globally (Roodman \& Lenssen, 1995). The U.S. Environmental Protection Agency (EPA) estimates that 170 million tons of buildingrelated construction and demolition (C\&D) debris was generated in the U.S. in 2003, with 61 percent coming from nonresidential and 39 percent from residential sources ${ }^{6}$. The EPA also estimates that 250 million tons of municipal solid waste is generated in the U.S. in a single year ${ }^{7}$.

2 National Trust for Historic Preservation. (2011). The Greenest Building: Quantifying the Environmental Value of Building Reuse, Accessed Jan. 26, 2012 via http://www.preservationnation.org/issues/sustainability/green-lab/usefulfacts-about-greenestbuildings.html

3 Department of Energy. (2011). Buildings Energy Data Book. Buildings Share of Electricity Consumption/Sales. Accessed October 26, 2011 via http://buildingsdatabook.eren.doe.gov/docs/xls_pdf/6.1.1.pdf

4 Environmental Information Administration. (2008). Assumptions to the Annual Energy Outlook. 5 U.S. Geological Survey. (2000). 2000 data.

6 U.S. Environmental Protection Agency. (2009). Estimating 2003 Building-Related Construction and Demolition Materials Amounts.

7 U.S. Environmental Protection Agency. (2008). Municipal Solid Waste Generation, Recycling, and Disposal in the United State: Facts and Figures for 2008. Available at: http://www.epa.gov/osw/nonhaz/municipal/pubs/msw2008rpt.pdf 


\section{Type of Green Labels}

Compared to conventional buildings, green buildings have superior environmental performance with better design and operation for energy conservation. Green buildings depend on the continuous improvement of building processes, technologies and performance to minimize negative environmental or health impacts, and contribute to environmental restoration and sustainable resource management of air, energy, land, water and other resources ${ }^{8}$.

Along with the green building movement, various green rating systems have emerged worldwide, initiated by both government and industry. Examples of these systems include: (a) U.K. first introduced the Building Research Establishment Environmental Assessment Method (BREEAM) in 1990, which is widely used in the U.K., and is the most widely adopted worldwide; (b) in 1996, the Leadership in Energy and Environmental Design (LEED) was developed by the U.S. Green Building Council (USGBC) for having building assessments in design and development stage, as well as management stage, which is used in the U.S.; (c) Japan also created the Comprehensive Assessment System for Built Environment Efficiency (CASBEE) in 2001, providing basic tools for design, development, and repair, which was developed by Japan Sustainable Building Consortium and is used in Japan; (d) Green Star, launched in 2003 by the Green Building Council of Australia, is designed to assess the environmental potential of office buildings. The National Australian Built Environment Rating System (NABERS), managed by New South Wales (NSW), is a performance-based system for

8 USGBC Research Committee. (2007). A National Green Building Research Agenda. Available at: http://www.usgbc.org/Docs/Archive/General/Docs3402.pdf 
existing buildings that rates commercial offices, hotels or residential buildings on the basis of their measured ongoing operational performance and impacts on the environment.

There is no unified global green-building rating system, but the U.S. real estate industry seems to be coalescing around the USGBC and its LEED green building rating systems (Nelson, 2007). LEED is a voluntary, consensus-based, market-driven program that provides third-party verification of green buildings. According to the statistics, LEED buildings avoided 0.35 percent of total U.S. $\mathrm{CO}^{2}$ emissions in 2011. The percentage of $\mathrm{CO}^{2}$ avoidance attributed to LEED buildings is projected to be 4.92 percent in $2030^{9}$. LEED projects are responsible for diverting over 80 million tons of waste diverted from landfills, which is expected to grow to over 540 million tons of waste diversion by $2030^{10}$. LEED projects will also reduce or treat over 13.6 billion gallons of stormwater per each $3 / 4$-inch storm event, and reduce by more than 30 percent wastewater generation comparing with 2010's estimate ${ }^{11}$. Due to more location-efficient LEED projects, the Green Building and Market Impact Report 2011 estimates that nearly 70 billion vehicle miles traveled will be reduced each year by 2030, resulting in over 3 billion gallons of gasoline saved each year, and the elimination of tons of particulate emissions. Many cities now specify LEED standards in their building codes, and for a growing number of practitioners, being green means being LEED-certified (Nelson, 2007).

9 Watson, Rob. (2011). Green Building and Market Impact Report - 2011. Available at: http://www.greenbiz.com/sites/all/themes/greenbiz/doc/GBMIR_2011.pdf

10 Watson, Rob. (2011). Green Building and Market Impact Report - 2011. Available at: http://www.greenbiz.com/sites/all/themes/greenbiz/doc/GBMIR_2011.pdf

11 Watson, Rob. (2011). Green Building and Market Impact Report - 2011. Available at: http://www.greenbiz.com/sites/all/themes/greenbiz/doc/GBMIR_2011.pdf 
Today, the LEED certification system covers New Construction \& Major Renovations, Existing Buildings, Core \& Shell, Commercial Interiors, Retail, Homes, Neighborhoods, Schools, and Healthcare. From individual buildings and homes to entire neighborhoods and communities, LEED guides the design, construction, and operation processes to address the entire building during its lifecycle. For instance, the LEED system for New Construction \& Major Renovations projects (LEED-NC v2.2) applies standards for (1) sustainable sites, (2) water efficiency, (3) energy \& atmosphere, (4) materials \& resources, (5) indoor environmental quality, and (6) innovation \& design process. Although energy efficiency is the single greatest distinguishing feature of green buildings, other building features are also very important including responsible land usage, conservation of natural resources and focuses on indoor conditions (Nelson, 2007). Different LEED green building rating systems in different certification versions have different scorecards of standards. The number of points a project earns determines the level of LEED certification that the project will receive, including certified - the lowest certification level followed by silver, gold, and platinum.

Another popular and widespread environmental certification system is called Energy Star. It is a voluntary program, provided by U.S. Environmental Protection Agency, that helps businesses and individuals save money and protect climate through superior energy saving. In 2011, Energy Star efforts saved more than 277 billion kilowatt-hours (kWh) about 5 percent of U.S. electricity demand and prevented 211 million metric tons of GHG 
emissions, equivalent to the annual emissions from 43 million vehicles ${ }^{12}$. Compared to LEED, Energy Star focuses on identifying and promoting energy-efficient products, not only buildings, in order to reduce energy consumption, improve energy security, and reduce pollution. Energy Star provides certification systems for products, new home construction and home improvement, commercial buildings, and the industrial sector. Energy Star ratings are on a scale of 1 to 100 and evaluate the energy performance of commercial and institutional building types and manufacturing facilities, including square footage and weekly operating hours, and monthly energy consumption, etc. Buildings have to upload 12 months of consecutive energy usage data, and receive a score of 75 or higher to qualify for the Energy Star. Energy Star energy performance ratings have been incorporated in LEED for Existing Buildings ${ }^{13}$. However, since Energy Star is limited to only energy efficiency, it cannot be considered a comprehensive green rating program (Nelson, 2007).

\section{Factors for Being Green-Certified Buildings}

Environmental certification systems have become a central element for a blend of governmental policies and voluntary market change that is attempting to produce reductions in carbon emissions from the real estate sector (Fuerst \& McAllister, 2009). Although it is touted that green-certified buildings have various economic, social and environmental benefits, in reality, it is uncertain whether and how well their 'greenness' is priced in the market.

12 U.S. Environmental Protection Agency. (November, 2012). ENERGY STAR and Other Climate Protection Partnerships 2011 Annual Report. Available at:

http://www.energystar.gov/ia/partners/publications/pubdocs/2011_AnnualReport_Final_low-res_12-1312.pdf?8c24-33c2

13 Energy Star from Wikipedia 
Sustainability has become an increasingly important attribute of economic activities, describing methods of production, qualities of consumption, and attributes of capital investment. This reflects popular concern with environmental preservation and may also reflect changes in tastes among consumers and investors (Eichholtz et al., 2010). Investments improving the energy efficiency or sustainability initiatives of real capital may have implications for providing important competitive advantages through market differentiation.

There are three potential sources of a price premium for green buildings. First, green technologies can save investors and building users costs. For example, better insulation and more energy-efficient equipment reduce operating costs for the property owner. However, the reduced user costs may result in a higher price if supply is not price elastic (Yoshida \& Sugiura, 2012).

Second, the important factor affecting the cost to go green are the mandates and incentives provided by local governments, utilities and other non-profits, trusts and foundations. If a city such as San Francisco requires Gold certification as of 2012 on office projects larger than 50,000 square feet, the marginal costs of achieving LEED certification up through the Gold level becomes zero since there will be no alternative. This is the case for many cities with regulations slated to become effective over the next several years (Miller et al., 2008). According to a survey conducted by the American Institute of Architects (AIA), the incentives that are most effective at stimulating green building include tax incentives, credits or rebates, density bonuses, and faster building permits. 
Third, it can be expected that the occupants' demand for green construction is heightened, since building users can gain greater utility or profits from green buildings, tenants and residents may enjoy pecuniary and non-pecuniary benefits, for example, better occupant health, higher satisfaction and productivity, lower utility bills, etc. Tenants of commercial buildings can pay higher rents if the use of green buildings is an important part of their corporate social responsibility. Home buyers can also pay higher prices if they are more satisfied with green residential units (Yoshida \& Sugiura, 2012). 


\section{CHAPTER 3 REVIEW OF LITERATURE}

\section{U.S. Studies of Green Office Properties}

The majority of previous research has been conducted to evaluate the economic value of green office buildings (Fuerst \& McAllister, 2009 \& 2011; Eichholtz et al., 2009 \& 2010;

Wiley et al., 2010; Pivo \& Fisher, 2010; Miller et al., 2008 \& 2009; Dermisi, 2009).

Whether green buildings can realize profit increases commensurate with the additional investment required at design and construction remains in doubt (Shimizu, 2010).

Several recent empirical studies look at the impact of green labels on commercial property value while controlling for a set of hedonic characteristics of buildings such as site area, stories, building size, building age, building class, renovated, year of sale, nearby amenities, and public transport, and confirm that customers are willing to pay a higher price for certified properties. The majority of these studies have been conducted using the LEED and Energy Star certification systems in the United States. Most of these recent evaluation studies focus on buildings certified between 2007 and 2009, which allows some comparability between LEED and Energy Star, since the requirements of each standard did not change during that period $^{14}$. TABLE 1 summarizes the newest and important green office market value studies in U.S. In these studies, certified buildings are compared to a sample of non-certified buildings, which were selected to include properties in the same submarket areas as the certified sample (Fuerst \& McAllister, 2009). A hedonic pricing model is employed to estimate the price differences between certified buildings and randomly selected non-certified buildings controlling for property,

14 Watson, Rob. (2011). Green Building and Market Impact Report - 2011. Available at: http://www.greenbiz.com/sites/all/themes/greenbiz/doc/GBMIR_2011.pdf 
locational, and neighborhood characteristics, and to indicate the effect of different certification systems in building rental and sales prices.

TABLE 1 Summary of U.S. Green Office Value Studies

\begin{tabular}{lllll}
\hline Study & $\begin{array}{l}\text { Rating } \\
\text { Systems }\end{array}$ & $\begin{array}{l}\text { Rental } \\
\text { Premium }\end{array}$ & $\begin{array}{l}\text { Sales Price } \\
\text { Premium }\end{array}$ & Occupancy Rate Premium \\
\hline $\begin{array}{l}\text { Fuerst and McAllister } \\
\text { (REE, 2011) }\end{array}$ & Energy Star & $4 \%$ & $26 \%$ & Not Addressed \\
\hline LEED & $5 \%{ }^{15}$ & $25 \%$ & Not Addressed \\
Fuerst and McAllister & Energy Star 2011$)$ & $3-4 \%$ & $18 \%$ & Energy Star: $1-3 \%$ \\
\hline Eichholtz et al & LEED & $4-5 \%$ & $25 \%$ & LEED: -5 - -6\% \\
(AER, 2010) & Energy Star & $3.3 \%$ & $19.1 \%$ & Bundled as 'effective rent': $10.0 \%$ \\
\hline $\begin{array}{l}\text { Eichholtz et al } \\
\text { (RICS, 2010) }\end{array}$ & Energy Star & $2.1 \%$ & $12.9 \%$ & Bundled as 'effective rent': $6.6 \%$ \\
\hline $\begin{array}{l}\text { Pivo and Fisher } \\
(2010)\end{array}$ & LEED & $5.8 \%$ & $11.1 \%$ & Bundled as 'effective rent': $5.9 \%$ \\
\hline $\begin{array}{l}\text { Wiley et al } \\
(2010)\end{array}$ & Energy Star & $2.7 \%$ & $8.5 \%$ & Not Addressed \\
\hline $\begin{array}{l}\text { Miller et al } \\
(2008)\end{array}$ & Energy Star & $7.3-8.6 \%$ & None & Energy Star: $10.2-11.0 \%$ \\
\hline LaED & $15.2-17.3 \%$ & None & LEED: $16.2-17.9 \%$ \\
\hline
\end{tabular}

Based on Green Building and Market Report ${ }^{18}$

Most of these studies use data collected from the CoStar Group database, which examines commercial leasing and sale activities across the U.S.

Two most recent green value studies by Fuerst and McAllister (2011) were published in Real Estate Economics and Ecological Economics. One found that green-labeled buildings command both a rental premium-4 percent in the case of Energy Star and 5 percent in the case of LEED-as well as a building value premium-26 percent in the case

15 One curious feature of this study was the fact that higher rental rate impacts did not always translate into higher building valuation

16 Not statistically significant

17 Not statistically significant

18 Watson, Rob. (2011). Green Building and Market Impact Report - 2011. Available at: http://www.greenbiz.com/sites/all/themes/greenbiz/doc/GBMIR_2011.pdf 
of Energy Star and 25 percent in the case of LEED ${ }^{19}$. Another suggested that office buildings with Energy Star or LEED eco-labels obtain a rental premium of approximately 3-5\%. Respective sales price premiums for Energy Star and LEED-labeled office buildings are $18 \%$ and $25 \%$. An occupancy premium could not be confirmed for LEED labeled office buildings and only a small positive occupancy premium was found for Energy Star (Fuerst \& McAllister, 2011).

Two studies from Eichholtz et al. (2010) — one through the peer-reviewed American Economic Review (AER), the other through the Royal Institute of Chartered Surveyors (RICS) - looked at 1,331 Energy Star-certified and 2,687 LEED-certified projects in the US office market ${ }^{20}$. These buildings were compared with nearby buildings using GIS techniques to identify all conventional office buildings within a radius of one quarter mile. Both statistical studies came to nearly identical conclusions: green certified office buildings command a rent premium of between 2 and 6 percent ${ }^{21}$. When factoring in the higher occupancy associated with the green label — the so-called 'effective' rent — the green margin grows to 6 percent to 10 percent $^{22}$. Moreover, the sales price of green office properties during 2007-2009 includes an estimated premium of 11 percent to 19 percent.

Another study from Wiley was released online in 2008 in Springer Science \& Business Media, and published in 2010 in Real Estate Finance and Economics, collected Class A

19 Watson, Rob. (2011). Green Building and Market Impact Report - 2011. Available at: http://www.greenbiz.com/sites/all/themes/greenbiz/doc/GBMIR_2011.pdf

20 Watson, Rob. (2011). Green Building and Market Impact Report - 2011. Available at: http://www.greenbiz.com/sites/all/themes/greenbiz/doc/GBMIR_2011.pdf

21 Watson, Rob. (2011). Green Building and Market Impact Report - 2011. Available at: http://www.greenbiz.com/sites/all/themes/greenbiz/doc/GBMIR_2011.pdf

22 Watson, Rob. (2011). Green Building and Market Impact Report - 2011. Available at: http://www.greenbiz.com/sites/all/themes/greenbiz/doc/GBMIR_2011.pdf 
office leasing activity in 46 markets nationwide. The results show that green-labeled buildings achieve significantly higher rents - estimated at 7.3 percent to 8.6 percent for Energy Star properties and 15.2 percent to 17.3 percent for LEED properties. Simultaneously, estimated occupancy rates are higher by approximately 10 percent to 11 percent for Energy Star properties and 16 percent to 18 percent for LEED properties (Wiley et al., 2010). Despite the findings of a significant premium in the rental market, it turned out that the market prices are no different for green-labeled office buildings.

These findings show that at the early period of the downturn in property markets, there was a significant green premium for rental and sales prices, and for occupancy rates of commercial office buildings in the U.S.

\section{Japan Studies of Green Condominiums}

Consistent with green commercial buildings, green residential buildings, especially green condominiums and lofts, have been increasingly designed and constructed in recent years. Although there is little research focusing on measuring the effect of a price premium in green-labeled housing in the U.S., two recent studies in Japan can provide some insights.

The most recent green condominium studies in Japan are by Yoshida and Shimizu (2010) and Yoshida and Sugiura (2012). The first paper used a hedonic approach to elucidate the effects of green labels and ratings under the Tokyo metropolitan government ordinance concerning the environmental performance of condominiums in the Tokyo condominium market. In Tokyo, the owners and developers of large apartment buildings are required to submit building environment plans to the metropolitan government. Based on the 
building environment planning system introduced in 2002, this program has required since October 2005 that information about four assessment items prescribed by the Tokyo metropolitan government be prepared and disclosed for construction or extension of buildings that exceed 10,000 square meters in total floor area. The four assessment items are (1) the building's heat insulation efficiency, (2) the equipment's energy efficiency, (3) the lifespan of the building, and (4) greening. For each of these items, buildings are rated on a scale of one to three stars. Also, to ensure the ratings are recognizable to consumers, they must be shown on all advertisements with plans for condominium units (including inserts, direct mail, and Internet advertisements) for which building environment plans have been submitted. In this way, these ratings can actually influence the behavior of consumers.

In general, the condominium unit price is affected by differences in (1) the condominium unit and building performance (proprietary area, number of rooms, accessibility, structure); (2) the surrounding environment (floor-to-area ratio, building-to-land, and zoning, local atmosphere, commercial zones, proximity to the central business district (CBD)); (3) location features (time from the nearest station to the terminal station, administrative ward level, railway line, proximity to the city center, latitude and longitude of buildings). The estimation results show that asking prices were around 4.7 percent higher for condominiums with green labels. For insulation, buildings with two stars in heat insulation showed a 6.8 percent transaction price premium. However, no premium was observed for three-star buildings. Energy efficiency brought a price discount of around 10 percent for both two- and three-star buildings when asking price 
discounts were included. For long-life ${ }^{23}$ condominiums, those with two and three stars exhibited a total price premium of 10.4 percent and 10.3 percent. As regards greening, the price premium was nil for buildings with two stars, but 3.5 percent for those with three stars (Yoshida \& Shimizu, 2010).

Furthermore, the study by Yoshida and Sugiura (2012) estimated the effects of itemized green scores on transaction prices using a rich set of data on condominium transactions and mandatory evaluation of environmental performance in Tokyo. Although green condominiums were on average traded at a premium, the premium was mainly attributed to the building age and quality. After controlling for relevant attributes, they found significant price discounts for newly constructed green condominiums. Discounts range from 6 percent to 11 percent depending on specifications. Using itemized scores in each of eight different measures in Tokyo Green Building Program (TGBP), this paper found that the long-life design mitigated price discounts, but other factors such as the use of eco-friendly materials, renewable energy, water reuse, and greening exacerbated discounts. A possible explanation was the capitalization of future user costs. The long-life design reduced an owner's life-cycle costs by making maintenance, renovation, and conversion easier. In contrast, planting, the use of eco-friendly materials and water circulation would increase future maintenance expenses and capital expenditures. These benefits and costs in the future should be capitalized into the initial price of a condominium (Yoshida \& Sugiura, 2012).

23 Long life, which by definition reduces future maintenance and renewal costs, promises a low future life cycle cost to property holders and adds to the initial purchase costs. 


\section{CHAPTER 4 STATEMENT OF PURPOSE}

Local governments are dependent on third-party organizations for certification of compliance with building standards (Miller et al., 2008). However, these third party certification systems have their advantages and disadvantages. At the same time, it is clearly possible to well-manage a non-green building or miss-manage a green building (Miller et al., 2009), and affect the consumers' willingness-to-pay for eco-certified green buildings. In this paper, rather than focusing on theoretically analyzing the strengths and weaknesses of these environmental certification systems, I use quantitative statistical analysis to examine the market value of green buildings and to evaluate whether green buildings realize property value increases commensurate with the initial investments required to achieve certification.

Although 'green markets' have expanded dramatically in some sectors of the economy, the valuation of green properties is a complex and multifaceted task. Until recently, only several statistical studies have estimated the impact of green labels on market value. However, through the literature review, I found that current studies all focus on commercial green-labeled properties in nationwide benchmark samples spread throughout the United States, rather than at the local or regional market level. In short, few studies have analyzed how prices of green condominiums are associated with ecolabel systems, with the exception of the two studies in Japan.

The lack of locally relevant and reliable information on the costs and benefits of operating green buildings may become one barrier to the growth of the green building market regionally. Meanwhile, in the local or regional market level, we may ignore 
differences across different regions that may affect the real estate market prices. So, instead of choosing a wide geographic area, I provide a citywide analysis of local multifamily residential real estate property sales prices to examine the degree to which the research method can be adopted and popularized in a smaller scale with a relatively limited dataset to guide the local green building market.

What the markets for green buildings have in common is an increasing willingness of customers to pay a premium which is potentially based on an increasing awareness of the environmental impact of production and consumption patterns. As green building and sustainable design become mainstream, lots of questions arise. Do green buildings maintain higher value than non-green buildings? My hypotheses guiding this research are:

1. People are willing to pay more to buy green-labeled condominium properties. The sales prices of green condominium properties certified by LEED system are higher than conventional properties.

2. Higher levels of certification (Platinum vs. Gold vs. Silver) deliver higher price premiums. 


\section{CHAPTER 5 DATA AND METHODOLOGY}

\section{Research Area}

The City of Portland and the State of Oregon have both identified the green building industry as an area of opportunity. Green architectural design and development businesses in the region are recognized as national leaders. As of September 2007, Portland had the greatest number of LEED certified buildings in the country. 'Place' matters - clearly Portland has meaningful advantages, in terms of both the levels of local awareness and demand, and the branding opportunity related to Portland's reputation as a leader in sustainable development and green industries, which makes Portland a suitable study area for my research since it has a larger and more mature market for green buildings.

\section{Certification system}

In this study, I use the LEED system that encourages the development of energy-efficient and sustainable buildings. The LEED is a point-based system where building projects earn LEED points for satisfying specific green building criteria. Today, LEED consists of a suite of nine rating systems for the design, construction and operation of buildings, homes and neighborhoods.

TABLE 2 lists the overall LEED rating systems and their different versions over time. 
TABLE 2 LEED Rating Systems and Versions

\begin{tabular}{ll}
\hline Rating Systems & Versions \\
\hline \multirow{2}{*}{$\begin{array}{l}\text { New Construction \& } \\
\text { Major Renovations }\end{array}$} & LEED 2009 for New Construction; \\
& New Construction v2.2; \\
& New Construction v2.1; \\
\hline \multirow{3}{*}{ Existing Buildings } & LEED 2009 for Existing Buildings; \\
& Existing Buildings 2008; \\
& Existing Buildings v2.0 \\
\hline \multirow{2}{*}{ Core \& Shell } & LEED 2009 for Core \& Shell; \\
\hline Commercial Interiors & Core \& Shell v2.0 \\
\hline \multirow{2}{*}{ Retail } & LEED 2009 for Commercial Interiors Commercial Interiors v2.0 \\
\hline Homes & LEED 2009 for Retail: New Construction \& Major Renovations; \\
\hline Neighborhood & LEED 2009 for Retail: Commercial Interiors \\
\hline Schools & LEED for Homes 2008 \\
\hline Healthcare & LEED for Neighborhood Development Pilot; \\
\hline Bold rating & LEED 2009 for Neighborhood Development \\
\hline
\end{tabular}

Bold rating systems and their versions are associated with this study.

Since LEED for New Construction v 2.2, 2.1, 2.0 and LEED for Neighborhood

Development Pilot are associated with this study, I provide LEED for New Construction

version 2.2 project credit categories and Points in TABLE 3 and LEED for Neighborhood

Development Pilot project credit categories and Points in TABLE 4 as follows:

\section{TABLE 3 LEED for New Construction v 2.2 Project Categories}

\begin{tabular}{lr}
\hline LEED for NC v 2.2 Project Credit Categories & Points \\
\hline Sustainable Sites & 14 Points \\
Water Efficiency & 5 Points \\
Energy \& Atmosphere & 17 Points \\
Materials \& Resources & 13 Points \\
Indoor Environmental Quality & 15 Points \\
Innovation \& Design Process & 5 Points \\
\hline Project Totals (Pre-Certification Estimates) & 69 Points \\
\hline Certified: 26-32 points Silver: 33-38 points Gold: 39-51 points Platinum: 52-69 points &
\end{tabular}


TABLE 4 LEED for Neighborhood Development Pilot Project Categories

\begin{tabular}{lr}
\hline LEED for ND Pilot Project Credit Categories & Points \\
\hline Smart Location \& Linkage & 30 Points \\
Neighborhood Pattern \& Design & 39 Points \\
Green Construction \& Technology & 31 Points \\
Innovation \& Design Process & 6 Points \\
\hline Project Totals (pre-certification estimates) & 106 Points \\
\hline Certified: 40-49 points, Silver: 50-59 points, Gold: 60-79 points, Platinum: 80-106 points & \\
\hline
\end{tabular}

Within each of the LEED credit categories, projects must satisfy particular prerequisites and earn points. The number of points a project earns determines the level of LEED certification the project receives. LEED certification is available in four progressive levels according to the following scale: Certified, Silver, Gold, and Platinum. Separate standards have been applied to new buildings, existing structures, and neighborhoods, etc. with different point categories.

\section{LEED Certification and Related Policies}

RREEF Research (2007) noted that projects certified at the lowest level have decreased steadily as a share of all LEED projects, while projects at the higher levels have risen. That is because developers are gaining greater experience with green products and a better understanding of how to score LEED points. Local governments also provide green mandates and incentives to require LEED-certified or to pursue higher LEED levels. For example, Los Angeles, CA, requires all projects greater than 50,000 SF, or 50 units, to meet LEED standards. In addition, the city is planning an expedited process for projects that meet or exceed LEED Silver (Nelson, 2007). Furthermore, the various local government incentive programs only kick in at the gold level. For instance, San 
Francisco, CA, gives priority permit review to all new and renovated buildings that achieve LEED Gold certification (Nelson, 2007).

\section{Data}

Oregon Metro serves as a clearinghouse for spatial data - providing a 'one stop shopping' approach to accessing regional data. This regional information is contained in the Regional Land Information System (RLIS). RLIS provides a timely geographic information system for the overall Portland Metropolitan Area, and updates taxlot information every three months. The taxlot dataset includes building and property information, such as parcel size, ownership, site address, building size, year built, sale date, sale price, etc. USGBC maintains data on approximately 40,100 LEED certified buildings all over the world.

According to the latest taxlot data of August 2012, I collected 1607 samples of conventional residential condominium units and 691 samples of LEED-NC certified condominium units, with valid site address, property size, and sale price from the postcrisis period of 2009 to March, 2012. Since the LEED public project directory is a worldwide list, it does not update building information in a timely manner. I confirmed City of Portland LEED building dataset with Portland Online Maps http://www.portlandmaps.com/, searched Portland green built \& LEED condos on http://www.highrises.com/portland/, as well as calling green building managers for their certification status. For instance, the Encore Condos registered LEED-NC Silver in 2008 and achieved Silver status in 2009, but it has not been recorded as a certified building in LEED directory. However, it has been publicized and accepted as a LEED-NC Silver 
online and the building manager confirmed that Encore Condos was certified as a Silver building in 2009. Combining these data, I list the following Portland green condo buildings in TABLE 5:

TABLE 5 Portland Green Condominium Buildings

\begin{tabular}{lll}
\hline Portland green condo buildings & LEED-ND Versions & Certification Level \\
\hline The Encore Condos & LEED NC 2.2 & Silver \\
The Metropolitan Condos & LEED NC 2.1 & Silver \\
The Westerly Condos & LEED NC 2.1 & Silver \\
Atwater Place Condos & LEED NC 2.1 & Gold \\
The Meriwether Condos & LEED NC 2.1 & Gold \\
The John Ross Condos & LEED NC 2.1 & Gold \\
The Civic Condos & LEED NC 2.1 & Gold \\
The Henry Condos & LEED NC 2.0 & Gold \\
The Casey Condos & LEED NC 2.1 & Platinum \\
937 Condos & LEED NC 2.2 & Platinum \\
\hline
\end{tabular}

Besides LEED-NC certified green condos, I also observed that there are three LEED-ND certified neighborhood development projects: The Eliot Tower (LEED ND 1.0 Pilot Only - Silver), South Waterfront Central District (LEED ND 1.0 Pilots Only - Gold), Hoyt Yard - North Pearl District (LEED ND 1.0 Pilot Only - Platinum). Due to the limited sample size, I covered all LEED-NC certified properties which are sold in 2009 to March 2012, while ignored the different versions of each rating system (LEED for New Construction and LEED for Neighborhood Development are associated with this study).

Using GIS techniques, I matched the filtered taxlot data with LEED certified condominium properties and neighborhoods, and selected a control sample of conventional condo unit sales within a radius of one mile. Unlike other empirical studies that using a quarter mile as a radius, I used one mile buffer. The reason is that those 
studies conduct a large sample size within a nationwide research area. While this is a city-wide study, data limitation is an obvious disadvantage. Moreover, Portland green condominium buildings are located in downtown or close to downtown area. After filtering data, the majority amount of non LEED-NC certified data are also within downtown area, and 69 percent (1110 divided by 1607) of data is within a one mile radius of green condominium units while the rest of data scatters all over the city area. Finally I received 691 LEED-NC certified condo units and 1110 control units, 742 condo units within LEED-ND certified neighborhoods and 1059 control units. FIGHRE 1 shows all LEED-ND certified green condominium properties and the non-LEED-ND certified condominium properties that within a one mile buffer. FIGURE 2 indicates that all related condominium properties are distributed in eight submarkets $(\mathrm{CBD}$, Johns Landing, Barbur Blvd/Capitol Hwy, Sylvan/Hillsdale, SW Close-In, NW Close-In, NW Outlying, and Guilds Lake). Three yellow regions show three LEED-ND certified neighborhood development projects. It is worth mentioning that LEED-NC certified condo units may or may not locate in LEED-ND certified neighborhoods. If within LEED-ND certified area, they become LEED-ND certified samples in this study, and if not, they turn into control samples, vice versa for the non-certified condo units. 
FIGURE 1 One Mile Buffer Map

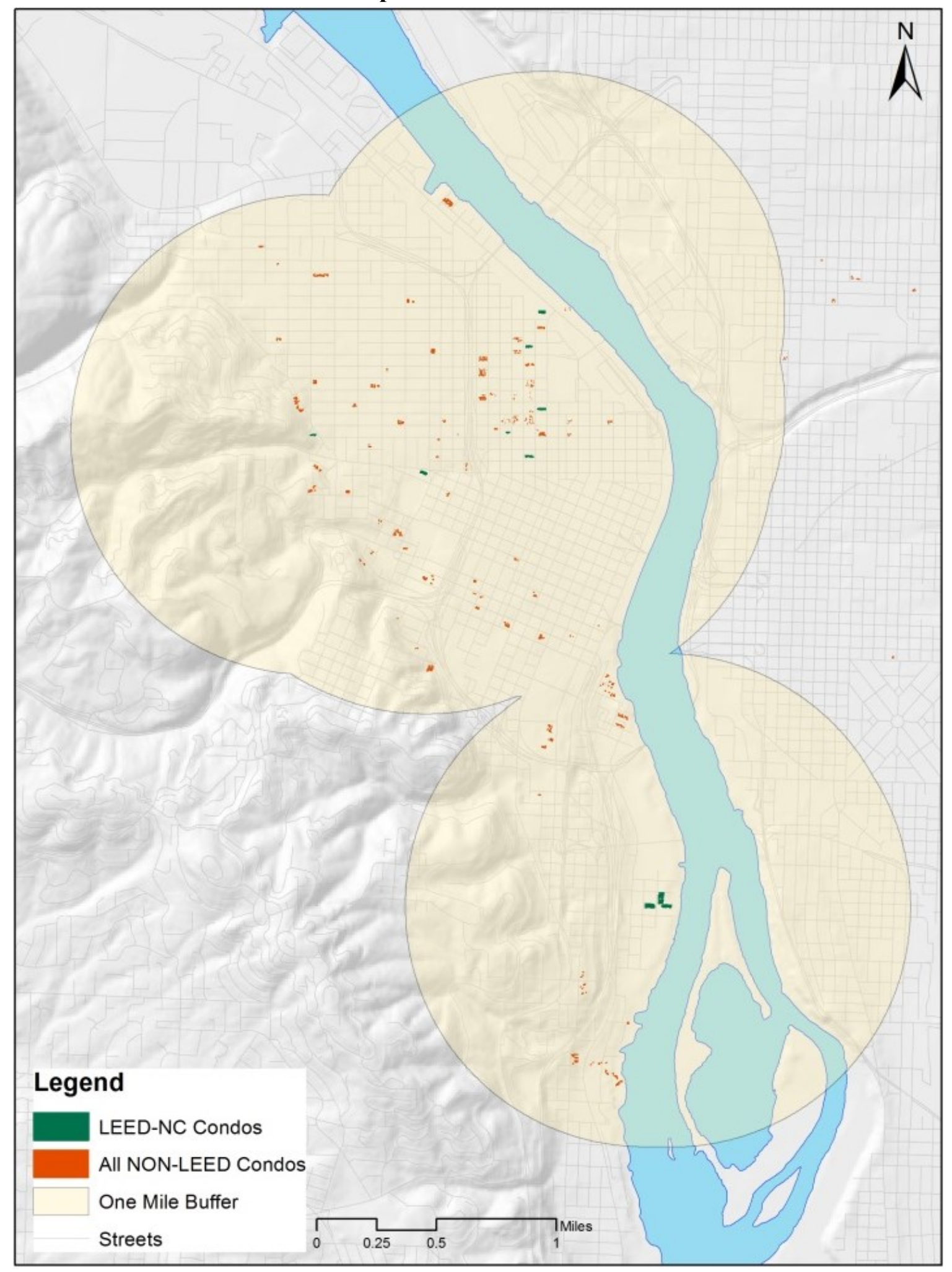


FIGURE 2 Submarkets Map

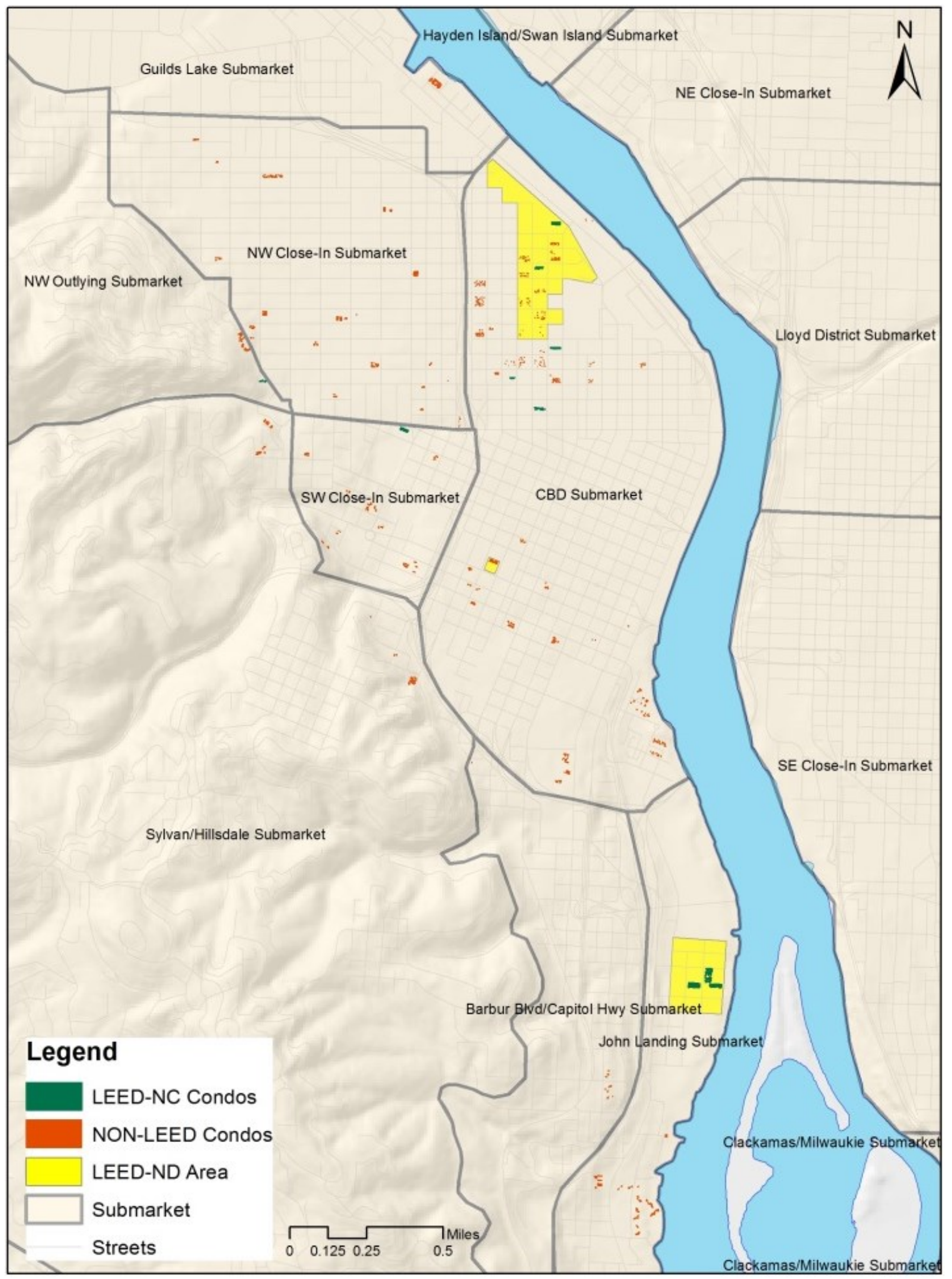




\section{Methodology}

Rosen (1974) first provided the basic hedonic pricing framework, and generalized that the hedonic price function covering any good or service consisted of a variety of utilitybearing characteristics. Therefore, hedonic regression becomes a revealed preference method of estimating demand or value. It decomposes the item being researched into its constituent characteristics, and obtains estimates of the implicit value of each characteristic. It has been commonly used in regression analysis, and economists and researchers frequently estimate hedonic pricing models in real estate economics to measure the relative importance of these independent explanatory variables on house and property prices. Housing characteristics include property characteristics, locational characteristics, and the neighborhood characteristics, etc. A property needs to be depended by some salient characteristics such as unit size, lot size, age, number of bedrooms and bathrooms, story, neighborhood, submarket, location, year of sale, quality and condition, amenities, etc. Because RLIS cannot provide many property characteristics such as number of bedrooms and bathrooms, quality and condition, my study cannot include them. However, due to the small research area - the city of Portland, this study allows me to conduct a more detailed research considering local factors, such as city center accessibility, river accessibility, public transportation accessibility, etc. This study includes (1) property characteristics: size, age, unit floor; (2) locational characteristics: distance to city center (city center accessibility), submarkets; (3) neighborhood characteristics: distance to nearest retail (retail accessibility), distance to Willamette river (river accessibility), distance to nearest light rail stop (public transit 
accessibility); (4) green characteristics: environmental certification status, the degree of certification; (5) time variable: year of sale.

In order to be able to estimate the unique contribution of the each characteristic using standard regression techniques, there are two well-known hedonic specifications. One is the fully linear model, and another is the logarithmic-linear model, including semi-log and log-log models. A usual view that the functional form is in fact nonlinear comes out the result that the semi-log functional form has become perhaps the most widely used functional form in hedonic studies. In this case, a critical issue in measuring the price effect of eco-labeling is to control for the fact that certified buildings may be newer, higher or located in more attractive locations or markets. Because of the skewed distribution of the housing sales price (FIGHRE 3), semi-log model (FIGHRE 4) becomes the preferred function form. It is also consistent with attribute utility theory, which posits diminishing marginal utility.

\section{FIGURE 3 Distribution of Sales Price}

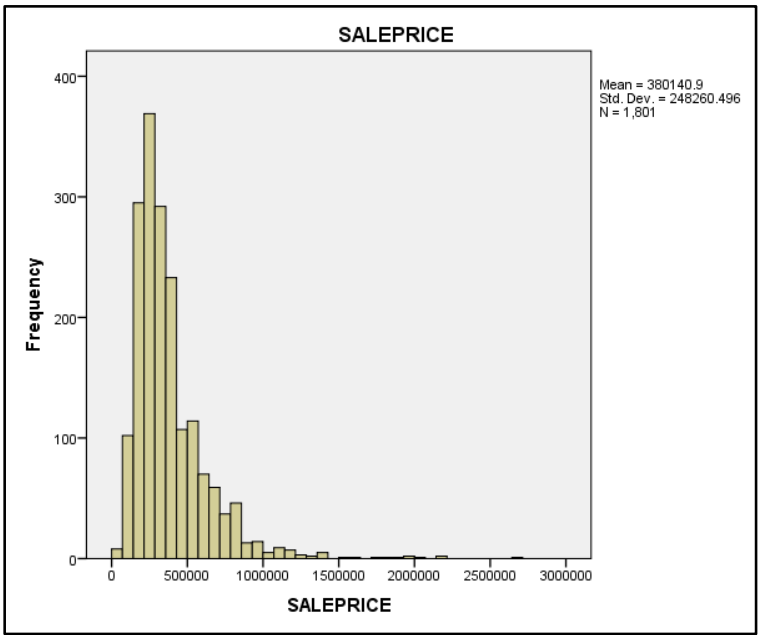

FIGURE 4 Distribution of Log Transformation of Sales Price

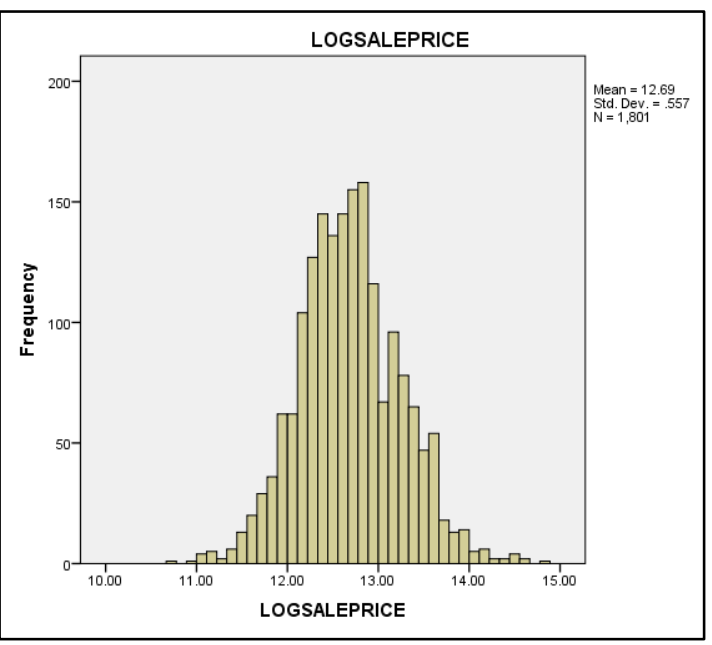


It takes the form:

$$
\text { In } \mathrm{Ri}=\alpha \mathrm{i}+\beta \mathrm{i} X \mathrm{i}+\varepsilon \mathrm{i}
$$

Where $\mathrm{Ri}$ is the sales price of residential condominium unit, $X_{\mathbf{1}}$ is a set of several explanatory characteristics, $\alpha \mathrm{i}$ and $\beta \mathrm{i}$ are the respective vectors of parameters to be estimated. $\varepsilon i$ is a random error. The hedonic weights assigned to each variable are equivalent to this characteristic's overall contribution to the asset sales prices (Rosen, 1974).

Hedonic Transaction Price Model: The regression for estimating price per square foot in sales transactions is estimated in the following way:

Ln Sales Price $($ dollars $)=\alpha \mathrm{i}+\beta 1$ (LEED-NC Dummy) $+\beta 2$

(LEED-NC Degree Dummy: Silver, Gold, Platinum) + $\beta 5$ (Size) + $\beta 6($ Age $)+\beta 7$ (Unit Floor) $+\beta 8($ Year of Sale Dummy:2009, 2010, $2011,2012)+\operatorname{Ln} \beta 9$ (Distance to City Center) $+\operatorname{Ln} \beta 10$ (Distance to Nearest Retail) $+\operatorname{Ln} \beta 11$ (Distance to River) $+\operatorname{Ln} \beta 12$ (Distance to Nearest Light Rail Stop) $+\beta 13$ (Submarket Dummy) $+\varepsilon i$ Ln Sales Price $($ dollars $)=\alpha \mathrm{i}+\beta 3$ (LEED-ND Dummy) $+\beta 4$ (LEED-ND Degree Dummy: Silver, Gold, Platinum $)+\beta 5($ Size $)+$ $\beta 6($ Age $)+\beta 7$ (Unit Floor) $+\beta 8$ (Year of Sale Dummy:2009, 2010, $2011,2012)+\operatorname{Ln} \beta 9$ (Distance to City Center) $+\operatorname{Ln} \beta 10$ (Distance to Nearest Retail) + $\operatorname{Ln} \beta 11$ (Distance to River) + $\operatorname{Ln} \beta 12$ (Distance to Nearest Light Rail Stop) $+\beta 13$ (Submarket Dummy) $+\varepsilon i$ 
Simplified into:

$$
\begin{aligned}
& \mathrm{In} \mathrm{Ri}=\alpha \mathrm{i}+\beta 1 \mathrm{NCi}+\beta 2 \mathrm{DD} 1 \mathrm{i}+\beta 5 \mathrm{SI}+\beta 6 \mathrm{AGi}+\beta 7 \mathrm{FLi}+\beta 8 \\
& \mathrm{SYi}+\operatorname{Ln} \beta 9 \mathrm{CCi}+\operatorname{Ln} \beta 10 \mathrm{REi}+\mathrm{Ln} \beta 11 \mathrm{RI}+\mathrm{Ln} \beta 12 \mathrm{LRi}+\beta 13 \\
& \mathrm{SDi}+\varepsilon \mathrm{i} \\
& \mathrm{In} \mathrm{Ri}=\alpha \mathrm{i}+\beta 3 \mathrm{NDi}+\beta 4 \mathrm{DD} 2 \mathrm{i}+\beta 5 \mathrm{SI}+\beta 6 \mathrm{AGi}+\beta 7 \mathrm{FLi}+\beta 8 \\
& \mathrm{SYi}+\operatorname{Ln} \beta 9 \mathrm{CCi}+\mathrm{Ln} \beta 10 \mathrm{REi}+\operatorname{Ln} \beta 11 \mathrm{RI}+\mathrm{Ln} \beta 12 \mathrm{LRi}+\beta 13 \\
& \mathrm{SDi}+\varepsilon \mathrm{i}
\end{aligned}
$$

Two models represent two LEED rating systems. One is LEED for New Construction (LEED-NC); another is LEED for Neighborhood Development (LEED-ND). In these equations, NC is LEED-NC dummy variable, DD1 represents LEED-NC degree dummy variables including silver, gold, and platinum. ND is LEED-ND dummy variable, DD2 represents LEED-ND degree dummy variables also including silver, gold, and platinum. SI represents the size of the condo property, AG measures the age from the year of construction, FL is the stories of the property, SY is the year of sale dummy variable including 2009, 2010, 2011, and 2012 (leaving 2009 out to prevent perfect collinearity), $\mathrm{CC}$ controls the distance to city center, which captures the distance variable from each sample to the central city which is Portland downtown Pioneer Square, RE controls the distance to the nearest retail, RI controls the distance to the Willamette river, LR means the light rail accessibility which values the distance to nearest light rail station, SD controls the submarket dummy including eight submarkets. $\varepsilon i$ is the error term which is assumed to be independent across observations and normally distributed with constant variance and a mean of zero. Submarkets are divisions of the primary market that are generally recognizable to the real estate industry and the business community by the 
names given to the areas. It is defined by specific geographic boundaries that serve to delineate core areas that are competitive with each other and constitute a generally accepted primary competitive set of areas. In this study, there are eight submarkets identified: CBD, Johns Landing, Barbur Blvd/Capitol Hwy, Sylvan/Hillsdale, SW CloseIn, NW Close-In, NW Outlying, and Guilds Lake (leaving CBD out to prevent perfect collinearity). It is worth mentioning that, to prevent multi-collinearity problem of time variable, I didn't include 'year built' dummy variable in this study, since I've already adopted 'year sale' dummy variable, as well as 'age' variable.

The variable names and corresponding summary statistics are provided in TABLE 6. 
TABLE 6 Variable Summary Statistics

\begin{tabular}{|c|c|c|c|c|c|}
\hline Variables & Description (Unit of Measure) & Min & Max & Mean & Std. Dev. \\
\hline \multicolumn{6}{|l|}{ Dependent Variables } \\
\hline SALEPRICE & The sales price of the sold condominium units (\$) & 47,700 & $2,700,000$ & $380,140.90$ & $248,260.50$ \\
\hline LOGSALEPRICE & Natural log-transformation of the sales price & 10.77 & 14.81 & 12.69 & .56 \\
\hline \multicolumn{6}{|l|}{ LEED-NC Variables } \\
\hline LEED-NC OR NONLEED-NC & $\begin{array}{l}\text { Property has been certified by LEED for New Construction } \\
\text { (Binary: } 1=y e s \text { ) }\end{array}$ & 0 & 1 & .38 & .49 \\
\hline LEED-NC SILVER & $\begin{array}{l}\text { Property is LEED-NC Silver certified unit } \\
\text { (Binary: } 1=\text { yes) }\end{array}$ & 0 & 1 & .08 & .28 \\
\hline LEED-NC GOLD & $\begin{array}{l}\text { Property is LEED-NC Gold certified unit } \\
\text { (Binary: } 1=\text { yes) }\end{array}$ & 0 & 1 & .25 & .43 \\
\hline LEED-NC PLATINUM & $\begin{array}{l}\text { Property is LEED-NC Platinum certified unit } \\
\text { (Binary: } 1=\text { yes) }\end{array}$ & 0 & 1 & .05 & .22 \\
\hline \multicolumn{6}{|l|}{ LEED-ND Variables } \\
\hline LEED-ND OR NONLEED-ND & $\begin{array}{l}\text { Neighborhood has been certified by LEED for } \\
\text { Neighborhood Development (Binary: } 1=\text { yes) }\end{array}$ & 0 & 1 & .41 & .49 \\
\hline $\begin{array}{l}\text { The Eliot Tower } \\
\text { LEED ND 1.0 Pilots Only SILVER }\end{array}$ & $\begin{array}{l}\text { Property is within LEED-ND Silver certified neighborhood } \\
\text { (Binary: } 1=\text { yes) }\end{array}$ & 0 & 1 & .03 & .18 \\
\hline $\begin{array}{l}\text { South Waterfront Central District } \\
\text { LEED ND 1.0 Pilots Only GOLD }\end{array}$ & $\begin{array}{l}\text { Property is within LEED-ND Gold certified neighborhood } \\
\text { (Binary: } 1=\text { yes) }\end{array}$ & 0 & 1 & .20 & .40 \\
\hline $\begin{array}{l}\text { Hoyt Yards-North Pearl District } \\
\text { LEED ND 1.0 Pilots Only } \\
\text { PLATINUM }\end{array}$ & $\begin{array}{l}\text { Property is within LEED-ND Platinum certified } \\
\text { neighborhood (Binary: } 1=\text { yes) }\end{array}$ & 0 & 1 & .18 & .38 \\
\hline \multicolumn{6}{|l|}{ Property Variables } \\
\hline SIZE & Size of the unit (square foot) & 275 & 4,772 & $1,162.20$ & 536.71 \\
\hline AGE & Age of the building (\#) & 5 & 110 & 24.79 & 31.21 \\
\hline UNIT FLOOR & Floor of the unit (\#) & 1 & 31 & 7.44 & 6.00 \\
\hline
\end{tabular}




\begin{tabular}{|c|c|c|c|c|c|}
\hline Time Variables & & & & & \\
\hline SALE YEAR 2009 & Year of sale $(1=2009)$ & 0 & 1 & .27 & .44 \\
\hline SALE YEAR 2010 & Year of sale $(1=2010)$ & 0 & 1 & .33 & .47 \\
\hline SALE YEAR 2011 & Year of sale $(1=2011)$ & 0 & 1 & .35 & .48 \\
\hline SALE YEAR 2012 & Year of sale $(1=2012)$ & 0 & 1 & .05 & .21 \\
\hline \multicolumn{6}{|l|}{ Neighborhood Variables } \\
\hline LOG DIST to RETAIL & Natural log-transformation of distance to nearest retail & 2.22 & 7.23 & 5.25 & .81 \\
\hline LOG DIST to RIVER & Natural log-transformation of distance to Willamette river & 4.23 & 8.84 & 7.26 & .98 \\
\hline LOG DIST to LRTSTOP & $\begin{array}{l}\text { Natural log-transformation of distance to nearest light rail } \\
\text { stop }\end{array}$ & 3.48 & 8.08 & 6.13 & .84 \\
\hline \multicolumn{6}{|l|}{ Location Variables } \\
\hline LOG DIST to CITY CENTER & Natural log-transformation of distance to city center & 6.65 & 9.41 & 8.37 & .53 \\
\hline CBD Submarket & $\begin{array}{l}\text { Property is within CBD Submarket } \\
\text { (Binary: } 1=\text { yes) }\end{array}$ & 0 & 1 & .54 & .50 \\
\hline John Landing Submarket & $\begin{array}{l}\text { Property is within John Landing Submarket } \\
\text { (Binary: 1=yes) }\end{array}$ & 0 & 1 & .23 & .42 \\
\hline $\begin{array}{l}\text { Barbur Blvd/Capitol Hwy } \\
\text { Submarket }\end{array}$ & $\begin{array}{l}\text { Property is within Barbur Blvd/Capitol Hwy Submarket } \\
\text { (Binary: 1=yes) }\end{array}$ & 0 & 1 & .00 & .07 \\
\hline Guilds Lake Submarket & $\begin{array}{l}\text { Property is within Guilds Lake Submarket } \\
\text { (Binary: } 1=\text { yes) }\end{array}$ & 0 & 1 & .01 & .12 \\
\hline NW Close-In Submarket & $\begin{array}{l}\text { Property is within NW Close-In Submarket } \\
\text { (Binary: 1=yes) }\end{array}$ & 0 & 1 & .10 & .30 \\
\hline NW Outlying Submarket & $\begin{array}{l}\text { Property is within NW Outlying Submarket } \\
\text { (Binary: 1=yes) }\end{array}$ & 0 & 1 & .02 & .13 \\
\hline SW Close-In Submarket & $\begin{array}{l}\text { Property is within SW Close-In Submarket } \\
\text { (Binary: 1=yes) }\end{array}$ & 0 & 1 & .07 & .25 \\
\hline Sylvan/Hillsdale Submarket & $\begin{array}{l}\text { Property is within Sylvan/Hillsdale Submarket } \\
\text { (Binary: } 1=\text { yes) }\end{array}$ & 0 & 1 & .02 & .14 \\
\hline
\end{tabular}




\section{CHAPTER 6 RESULTS AND DISCUSSION}

\section{Descriptive Statistics}

The descriptive statistics of the sample properties are displayed in TABLE 7. There are significant differences between LEED-NC certified and non-certified properties, and among different certification levels. The LEED properties tend to be newer. The mean age of the LEED-NC certified properties is 6.48 years, compared to an overall average age of 24.79 years. The average unit price for the LEED certified properties is higher than unit price of whole sample. By comparing the unit price of properties across different LEED certification levels, it turns out that the Platinum properties have the highest mean sale price per square foot, and the Silver property is also valued higher than the LEED-NC average level. However, the mean for sale price per square foot of the Gold properties is much lower than the LEED-NC average, and even lower than the overall sample average.

TABLE 7 Descriptive Statistics of Overall Sample with LEED-NC Samples

\begin{tabular}{|c|c|c|c|c|c|}
\hline & $\begin{array}{c}\text { SALEPRICE } \\
\text { (\$) }\end{array}$ & $\begin{array}{c}\text { PRICEPERSQFT } \\
\text { (\$ psf) }\end{array}$ & SIZE (sq ft) & AGE & $\begin{array}{c}\text { UNIT } \\
\text { FLOOR }\end{array}$ \\
\hline OVERALL & $380,140.90$ & 318.72 & $1,162.20$ & 24.79 & 7.44 \\
\hline LEED-NC & $463,822.79$ & 337.89 & $1,330.54$ & 6.48 & 10.84 \\
\hline LEED-NC SILVER & $479,704.61$ & 395.30 & $1,187.08$ & 6.22 & 8.96 \\
\hline LEED-NC GOLD & $409,074.24$ & 297.96 & $1,331.11$ & 6.82 & 11.91 \\
\hline LEED-NC PLATINUM & $703,589.82$ & 437.05 & $1,564.77$ & 5.26 & 8.72 \\
\hline
\end{tabular}

The descriptive statistics of the whole sample and properties located within LEED-ND certified neighborhoods are displayed in TABLE 8 . There are clearly some differences between LEED-ND certified and non-certified properties, and different certification levels. The former tend to be newer. The mean age of the LEED-NC certified properties 
is 7.6 years, compared to an overall average age of 24.79 years. While, there is relative little difference in terms of the mean of sale price per square foot, size, and unit floor. Controlling for the differences of certification levels between the samples, it turns out that properties within the Silver neighborhood has the highest mean sale price per square foot, even slightly higher than the properties within the Platinum neighborhood. And both are much larger than the LEED-ND average. However, the mean sale price per square foot for properties within the Gold neighborhood is much lower than the LEED-NC average level, and even lower than the overall sample average.

TABLE 8 Descriptive Statistics of Overall Sample with LEED-ND Samples

\begin{tabular}{lcccrr}
\hline & $\begin{array}{c}\text { SALEPRICE } \\
\mathbf{( \$ )}\end{array}$ & $\begin{array}{c}\text { PRICEPERSQFT } \\
\mathbf{( \$ ~} \mathbf{~ p s f})\end{array}$ & SIZE (sq ft) & AGE & $\begin{array}{c}\text { UNIT } \\
\text { FLOOR }\end{array}$ \\
\hline OVERALL & $380,140.90$ & 318.72 & $1,162.20$ & 24.79 & 7.44 \\
LEED-ND & $415,742.17$ & 326.98 & $1,248.86$ & 7.60 & 9.63 \\
LEED-ND SILVER & $472,613.37$ & 367.07 & $1,254.05$ & 7.00 & 8.71 \\
LEED-ND GOLD & $415,161.43$ & 288.91 & $1,393.37$ & 6.63 & 12.69 \\
LEED-ND PLATINUM & $405,315.17$ & 362.49 & $1,083.36$ & 8.81 & 6.33 \\
\hline
\end{tabular}

\section{Hedonic Regression Results and the Price Premium}

There are 499 LEED-NC certified units within the LEED-ND samples. To prevent a multi-collinearity problem, I separated LEED-NC and LEED-ND into two regression models.

TABLE 10 presents the coefficients, standard errors and significance statistics for the six models. The six models all have a relatively good overall fit with an adjusted $\mathrm{R}^{2}$ at or above 0.775 . Most of the controlling variables show statistically significant coefficients with the expected sign. 
Models 1 to 3 introduce the LEED-NC variable, and models 4 to 6 input three levels of LEED-NC certification. In both three models (models 1 to 3 and models 4 to 6), I consider three alternatives of location variables: (1) only log distance to city center, (2) only submarket dummy variables, (3) both, while all else being equal. Model 1 indicates that LEED-NC is associated with a 5.8 percent increase in residential condominium property price, while in Model 2 and 3 LEED-NC raises property sales price by 16 percent. Model 4 reflects that LEED-NC Silver elevates the sales price by 24.8 percent, and LEED-NC Platinum brings a 21.1 percent increase on property value. However, LEED-NC Gold is associated with an 11.5 percent discount on property price. When I consider the submarket variables in Model 5 and 6, the LEED-NC Silver and Platinum add approximately 20 percent and 22.1 percent additional value to the residential property, while LEED-NC Gold is not statistically significant. The result raises a set of questions: why does LEED-NC Gold be found a significant price discount and a lower depreciation rate for newly constructed green condominiums? Even after adding submarket variables, there is still not significant sales price premium for LEED-NC Gold. Does this mean that Gold isn't worth it? If LEED-NC Silver has an equal or even higher price premium, does it mean that we don't need to spend more money to get a higher level of certification?

As I've mentioned in the purpose statement, this is a citywide research area, so that I ignore regional differences, while focusing on local situations. In this case, it is unique that about 80 percent LEED-NC Gold certified samples (including the Atwater Place Condos, the Meriwether Condos, and the John Ross Condos) are located in the Johns 
Landing submarket, belonging to South Waterfront Central District. It is a brand new redevelopment area, along the South edge of downtown, along the waterfront of the Willamette River, with convenient amenities and public transit. Since 2003, developers and the City of Portland have turned the mostly vacant industrial district into 100 percent green high-rise condos and apartments, but the housing collapse and credit crisis have walloped the neighborhood with slow sales and mortgage defaults ${ }^{24}$. The John Ross has been hit particularly hard by the recession. Sales opened in 2005 when buyers were desperate to lock up high-rise condos as investments, but the building finished in 2007 just as the subprime market nose-dived ${ }^{25}$. Because of the grim situation of housing market, a large number of condos was been sold in real estate auctions which is to use low minimum bids and an advertising blitz to generate fresh sales leads. As one real estate professional said, 'the minimum bids, on average, will be 47 percent below the current list prices and 70 percent below the highest listed prices'. Although the winning bid would be much higher than the starting price, the sales price still was far less than original owner paid. The low price of South Waterfront Central District reflects the realities of the downbeat housing market since 2007.

Another fact also may affect the sales price of LEED-NC Gold certified samples in the Civic Condominium green building. The Civic Redevelopment project consists of a condominium tower and low-rise housing project which is owned by Housing Authority

24 Frank, Ryan. (2010). South Waterfront sell off slogs on with Sunday's John Ross Auction. The Oregonian. Available at: http://blog.oregonlive.com/frontporch/2010/04/south_waterfront_sell_off_slog.html 25 Frank, Ryan. (2010). South Waterfront sell off slogs on with Sunday's John Ross Auction. The Oregonian. Available at: http://blog.oregonlive.com/frontporch/2010/04/south_waterfront_sell_off_slog.html 
of Portland. The Civic Condominiums contain 261 mixed income units, while the Morrison Apartments contain 130 units of low-income housing. The project received support from the Green Investment Fund (GIF) in 2005 for green building strategies ${ }^{26}$. Both the Civic Condominiums and the Morrison Apartments were completed in 2007 and certified in 2008 as LEED-NC Gold buildings. Because of the nature of the Civic Redevelopment, the project costs can be lower than regular projects. And as well as the downturn housing market since 2007, it comes out that the mean of sale price per square foot is also much lower than the overall average level.

TABLE 9 shows that those four LEED-NC Gold certified condos are atypically but reasonably lower than the LEED-NC average price, and are much lower than other LEED-NC certified levels. However, the Henry Condos is part of the Brewery Blocks neighborhood, which is the nation's largest sustainable urban redevelopment ${ }^{27}$. It was built in 2004, certified in 2005, and sold out before completion by an astounding nine months. Although the transaction samples in the period of 2009 to 2012 are only a few, those data reveals representative sales prices of LEED-NC Gold certified properties.

26 The Cadmus Group, Inc. / Energy Services. (2011). GIF Project M\&V Plan and Report: Civic Redevelopment. Available at: 2011, http://www.portlandoregon.gov/bps/article/437410 27 Pearl District Properties. http://www.pearldistrictproperties.com/pearl-district-henry.html 


\section{TABLE 9 Comparison of LEED-NC Gold Condominium Sales Prices}

\begin{tabular}{|c|c|c|}
\hline & $\begin{array}{c}\text { Units } \\
\#\end{array}$ & $\begin{array}{c}\text { Mean of Sale Price } \\
\$ \text { psf }\end{array}$ \\
\hline Overall & 1801 & 318.72 \\
\hline LEED-NC & 691 & 337.89 \\
\hline LEED-NC Silver & 152 & 395.30 \\
\hline LEED-NC Gold & 447 & 297.96 \\
\hline Atwater Place Condos & 133 & 336.87 \\
\hline The Meriwether Condos & 59 & 295.48 \\
\hline The John Ross Condos & 170 & 249.11 \\
\hline The Civic Condos & 58 & 273.35 \\
\hline The Henry Condos & 27 & 472.15 \\
\hline LEED-NC Platinum & 92 & 437.05 \\
\hline
\end{tabular}

TABLE 10 has confirmed my first hypotheses, that people are willing to pay more to buy green-labeled condominium properties on the whole. The sales prices of green condominium properties certified by LEED-NC Silver and Platinum are significantly higher than conventional properties. Consistent with the previous studies, one can assume that in this case if the LEED-ND Gold sales prices are within a rational scope like Silver and Platinum, the overall price premium could go up to 20-25 percent. 
TABLE 10 Regression Results of LEED-NC Certification and Sales Prices

\begin{tabular}{|c|c|c|c|c|c|c|c|c|c|c|c|c|}
\hline \multirow[b]{2}{*}{ Variables } & \multicolumn{2}{|c|}{ Model 1} & \multicolumn{2}{|c|}{ Model 2} & \multicolumn{2}{|c|}{ Model 3} & \multicolumn{2}{|c|}{ Model 4} & \multicolumn{2}{|c|}{ Model 5} & \multicolumn{2}{|c|}{ Model 6} \\
\hline & Coeff. & $\mathbf{p}$ & Coeff. & $\mathbf{p}$ & Coeff. & $\mathbf{p}$ & Coeff. & $\mathbf{p}$ & Coeff. & $\mathbf{p}$ & Coeff. & $\mathbf{p}$ \\
\hline (Constant) & 13.631 & .000 & 12.510 & .000 & 12.378 & .000 & 13.018 & .000 & 12.609 & .000 & 12.599 & .000 \\
\hline \multicolumn{13}{|l|}{ LEED-NC Variables } \\
\hline LEED-NC OR NONLEED-NC (1=yes) & .058 & .001 & .160 & .000 & .160 & .000 & & & & & & \\
\hline LEED-NC SILVER (1=yes) & & & & & & & .248 & .000 & .199 & .000 & .198 & .000 \\
\hline LEED-NC GOLD (1=yes) & & & & & & & -.115 & .000 & .047 & .101 & .048 & .101 \\
\hline LEED-NC PLATINUM (1=yes) & & & & & & & .211 & .000 & .221 & .000 & .221 & .000 \\
\hline \multicolumn{13}{|l|}{ Property Variables } \\
\hline SIZE & .001 & .000 & .001 & .000 & .001 & .000 & .001 & .000 & .001 & .000 & .001 & .000 \\
\hline AGE & -.002 & .000 & -.002 & .000 & -.002 & .000 & -.002 & .000 & -.002 & .000 & -.002 & .000 \\
\hline UNIT FLOOR & .002 & .069 & .005 & .000 & .005 & .000 & .006 & .000 & .006 & .000 & .006 & .000 \\
\hline \multicolumn{13}{|l|}{ Time Variables } \\
\hline SALE YEAR 2010 (1=yes) & -.096 & .000 & -.083 & .000 & -.083 & .000 & -.082 & .000 & -.081 & .000 & -.081 & .000 \\
\hline SALE YEAR 2011 (1=yes) & -.096 & .000 & -.100 & .000 & -.101 & .000 & -.102 & .000 & -.100 & .000 & -.100 & .000 \\
\hline SALE YEAR 2012 (1=yes) & -.115 & .000 & -.089 & .002 & -.088 & .002 & -.110 & .000 & -.093 & .001 & -.093 & .001 \\
\hline \multicolumn{13}{|l|}{ Neighborhood Variables } \\
\hline LOG DIST to RETAIL & -.083 & .000 & -.078 & .000 & -.079 & .000 & -.100 & .000 & -.088 & .000 & -.088 & .000 \\
\hline LOG DIST to RIVER & -.036 & .000 & -.040 & .000 & -.037 & .003 & -.035 & .000 & -.039 & .001 & -.039 & .002 \\
\hline LOG DIST to LRT STOP & -.002 & .857 & .011 & .306 & .009 & .426 & -.009 & .347 & -.002 & .883 & -.002 & .877 \\
\hline \multicolumn{13}{|l|}{ Location Variables } \\
\hline LOG DIST to CITY CENTER & -.132 & .000 & & & .015 & .502 & -.044 & .019 & & & .001 & .960 \\
\hline Johns Landing Submarket (1=yes) & & & -.363 & .000 & -.372 & .000 & & & -.239 & .000 & -.240 & .000 \\
\hline $\begin{array}{l}\text { Barbur Blvd/Capitol Hwy Submarket } \\
(1=\text { yes })\end{array}$ & & & -.230 & .006 & -.242 & .004 & & & -.189 & .023 & -.190 & .026 \\
\hline Guilds Lake Submarket (1=yes) & & & -.010 & .853 & -.012 & .830 & & & .048 & .402 & .048 & .408 \\
\hline NW Close-In Submarket (1=yes) & & & -.045 & .086 & -.055 & .067 & & & -.018 & .505 & -.019 & .543 \\
\hline NW Outlying Submarket (1=yes) & & & .075 & .176 & .066 & .250 & & & .097 & .086 & .096 & .096 \\
\hline
\end{tabular}




\begin{tabular}{|c|c|c|c|c|c|c|c|c|c|c|}
\hline SW Close-In Submarket (1=yes) & & -.235 & .000 & -.238 & .000 & & -.164 & .000 & -.164 & .000 \\
\hline Sylvan/Hillsdale Submarket (1=yes) & & -.118 & .017 & -.123 & .014 & & -.074 & .136 & -.075 & .139 \\
\hline Adjusted R Square & .775 & & .809 & & .809 & .804 & & .812 & & .812 \\
\hline Number of Observations & 1801 & & 1801 & & 1801 & 1801 & & 1801 & & 1801 \\
\hline
\end{tabular}

a. Dependent Variable: log sale price of condominium unit.

b. The control sample consists of all condominium units within a 1 mile radius of each certified unit for which comparable data are available. All observations are current as of August 2012.

c. There are 691 certified samples and 1110 non-certified samples.

d. Retail is NACIS 44-45 Retail Trade. 
TABLE 11 presents the coefficients, standard errors and significance statistics for the six models. The six models all have a relatively good overall fit with an adjusted R2 equal or above 0.774 . Most of the controlling variables show statistically significant coefficients with the expected sign.

Models 7 to 9 introduce LEED-ND variable, and models 10 to 12 input three levels of LEED-ND certification. In both three models (models 7 to 9 and models 10 to 12), I also consider three alternatives of location variables: (1) only log distance to city center, (2) only submarket dummy variables, (3) both, while all else being equal. Model 7 indicates that condo property within LEED-ND certified neighborhood is statistically insignificant in residential condominium property price, while in models 8 and 9 LEED-ND variable is marginally significant, which raises property sales price by over 3 percent. Model 10 reflects that LEED-ND Platinum elevates the property sales price by 8.3 percent. LEEDND Silver brings no statistically significant increase on property value. However, LEEDND Gold is associated with a 21.4 percent discount on property price. When I consider the submarket variables in models 11 and 12, the LEED-ND Platinum is still marginally significant adding over 4 percent additional value to the residential property. And LEEDND Silver brings no statistically significant increase in property value, so does LEEDND Gold variable.

When I analyze TABLE 10, I explain the reason why LEED-ND Gold is found a significant price discount and a lower depreciation rate for newly constructed green condominiums and even after adding submarket variables. The results of TABLE 11 also reflect that there is not significant sales price premium for LEED-ND Gold. 
And TABLE 11 may also give an answer for TABLE 10 that why LEED-NC Silver has an equal or even higher price premium with LEED-NC Platinum. Besides LEED Gold neighborhood contains three LEED Gold buildings, LEED Platinum neighborhood also contains two LEED Silver buildings, which are the Encore Condos and the Metropolitan Condos. The value of green properties in two LEED Silver buildings within significant LEED Platinum neighborhood is raised additionally.

In sum, my second hypothesis cannot be confirmed or refuted by this case with the existing samples. 
TABLE 11 Regression Results of LEED-ND Certification and Sales Prices

\begin{tabular}{|c|c|c|c|c|c|c|c|c|c|c|c|c|}
\hline \multirow[b]{2}{*}{ Variables } & \multicolumn{2}{|c|}{ Model 7} & \multicolumn{2}{|c|}{ Model 8} & \multicolumn{2}{|c|}{ Model 9} & \multicolumn{2}{|c|}{ Model 10} & \multicolumn{2}{|c|}{ Model 11} & \multicolumn{2}{|c|}{ Model 12} \\
\hline & Coeff. & $\mathbf{p}$ & Coeff. & $\mathbf{p}$ & Coeff. & $\mathbf{p}$ & Coeff. & $\mathbf{p}$ & Coeff. & $\mathbf{p}$ & Coeff. & $\mathbf{p}$ \\
\hline (Constant) & 13.571 & .000 & 12.698 & .000 & 12.558 & .000 & 12.958 & .000 & 12.702 & .000 & 12.609 & .000 \\
\hline \multicolumn{13}{|l|}{ LEED-ND Variables } \\
\hline LEED-ND OR NONLEED-ND (1=yes) & -.010 & .588 & .034 & .054 & .031 & .083 & & & & & & \\
\hline $\begin{array}{l}\text { The Eliot Tower } \\
\text { LEED-ND } 1.0 \text { Pilots Only SILVER ( } 1=\text { yes) }\end{array}$ & & & & & & & .027 & .466 & .031 & .371 & .038 & .327 \\
\hline $\begin{array}{l}\text { South Waterfront Central District } \\
\text { LEED-ND 1.0 Pilots Only GOLD ( } 1=\text { yes })\end{array}$ & & & & & & & -.214 & .000 & -.023 & .596 & -.022 & .618 \\
\hline $\begin{array}{l}\text { Hoyt Yards-North Pearl District } \\
\text { LEED-ND } 1.0 \text { Pilots Only PLATINUM } \\
(1=\text { yes })\end{array}$ & & & & & & & .083 & .000 & .045 & .024 & .040 & .087 \\
\hline \multicolumn{13}{|l|}{ Property Variables } \\
\hline SIZE & .001 & .000 & .001 & .000 & .001 & .000 & .001 & .000 & .001 & .000 & .001 & .000 \\
\hline AGE & -.002 & .000 & -.002 & .000 & -.002 & .000 & -.002 & .000 & -.002 & .000 & -.002 & .000 \\
\hline UNIT FLOOR & .004 & .001 & .009 & .000 & .009 & .000 & .010 & .000 & .009 & .000 & .009 & .000 \\
\hline \multicolumn{13}{|l|}{ Time Variables } \\
\hline SALE YEAR 2010 (1=yes) & -.100 & .000 & -.092 & .000 & -.092 & .000 & -.101 & .000 & -.093 & .000 & -.093 & .000 \\
\hline SALE YEAR 2011 (1=yes) & -.100 & .000 & -.110 & .000 & -.110 & .000 & -.115 & .000 & -.111 & .000 & -.111 & .000 \\
\hline SALE YEAR 2012 (1=yes) & -.119 & .000 & -.108 & .000 & -.107 & .000 & -.127 & .000 & -.110 & .000 & -.110 & .000 \\
\hline \multicolumn{13}{|l|}{ Neighborhood Variables } \\
\hline LOG DIST to RETAIL & -.091 & .000 & -.096 & .000 & -.096 & .000 & -.099 & .000 & -.097 & .000 & -.097 & .000 \\
\hline LOG DIST to RIVER & -.040 & .000 & -.053 & .000 & -.050 & .000 & -.051 & .000 & -.051 & .000 & -.050 & .000 \\
\hline LOG DIST to LRT STOP & -.005 & .689 & .013 & .259 & .010 & .407 & .001 & .928 & .009 & .425 & .007 & .565 \\
\hline \multicolumn{13}{|l|}{ Location Variables } \\
\hline LOG DIST to CITY CENTER & -.111 & .000 & & & .017 & .472 & -.030 & .208 & & & .013 & .687 \\
\hline Johns Landing Submarket ( $1=$ yes) & & & -.307 & .000 & -.316 & .000 & & & -.248 & .000 & -.259 & .000 \\
\hline
\end{tabular}


Barbur Blvd/Capitol Hwy Submarket (1=yes)

Guilds Lake Submarket (1=yes)

NW Close-In Submarket (1=yes)

NW Outlying Submarket (1=yes)

SW Close-In Submarket (1=yes)

Sylvan/Hillsdale Submarket (1=yes)

Adjusted R Square

Number of Observations

a. Dependent Variable: log sale price of condominium unit.

b. The control sample consists of all condominium units within a 1 mile radius of each certified unit for which comparable data are available. All observations are current as of August 2012.

c. There are 742 certified samples and 1059 non-certified samples.

d. Retail is NACIS 44-45 Retail Trade. 


\section{Study Limitations}

As a first tentative study of measuring the effect of green condominiums on property value in U.S. this study has certain limitations.

First, this utilizes a small unit sample size and a small building sample size. There is not enough variety among unit types to fully answer the questions raised, with no or little difference between variables, such as certified or non-certified, certified level, building age, property size, distance to city center, nearest retail, river, nearest light rail stop, and submarket. The limited number of unit attributes means that the LEED premium may be confounded with excluded attributes, possibly associated with quality attributes.

Moreover, approximately 80 percent of the LEED-NC Gold certified samples are located in the Johns Landing submarket, sharing a similar distance to city center, as well as distance to the Willamette River. When I introduced the submarket dummy variables into model, it shows collinearity with variance inflation factors (VIF) for these variables over 4.

In addition, the fact in TABLE 10 and 11 indicate that public transit access is insignificant. It may be due to the generally high level of accessibility to transit that prevails in my case.

The most important limitation is that in this case I could not test my hypotheses, especially the second one, as thoroughly as would be useful. However, those two hypotheses can be tested again with more scientific data collection, for instance, increasing the sample size by enlarging the sale of year range, and randomly selecting a 
certain number of residential property samples for both certified and non-certified buildings. 


\section{CHAPTER 7 CONCLUSION AND POLICY IMPLICATIONS}

This paper is a preliminary and experimental analysis of the capitalization effect of green certification on the residential condominium market at a city level, using the City of Portland as a representative research case. This study tested my two hypotheses and the final result only supports one of the two hypotheses. Overall, with the evidence from Portland, I can draw the conclusion that there is statistically significant sales price premium for LEED-NC certified condos on average, as well as LEED-NC Silver and Platinum certified condos. Also the condos located within LEED-ND Platinum certified neighborhood receive a significant price premium. However, the price premium may not go up as the certification level (Silver, Gold, and Platinum) increases. In general, these results indicate that consumers of condos are willing to pay a higher price to buy 'Green' properties, and energy-efficient residential condominium buildings may enjoy stronger market demand.

It is worth mentioning that the cost per square foot for building seeking LEED certification falls into the existing range of costs for buildings not seeking LEED certification $^{28}$. Moreover, an upfront investment of two percentages in green building design, on average, results in life cycle savings of 20 percent of the total construction costs - more than ten times the initial investment ${ }^{29}$. This paper estimates that LEED capitalized value contribute important information in determining the economic viability

28 Langdon, Davis. (2007). Cost of Green Revisited: Reexamining the Feasibility and Cost Impact of Sustainable Design in the Light of Increased Market Adoption. Available at: http:/www.davislangdon.com/upload/images/publications/USA/The\%20Cost\%20of\%20Green\%20Rev isited.pdf

29 Kats, Greg. (2003). The Costs and Financial Benefits of Green Buildings: A Report to California's Sustainable Building Task Force. Available at: http://www.usgbc.org/Docs/News/News477.pdf 
of LEED designs. For condo developers, this study should encourage them to integrate green design into their residential buildings because the extra cost for the green design will be paid back in the market. However, it is an issue of the high certification fee of LEED system. Based on project's rating system and size, certification fee range for LEED-NC combined design and construction review is from $\$ 2,250$ to $\$ 27,500$, let alone the expedited fee and appeals fee if applicable. In conclusion, the investors need to compare the estimated capitalization value against the additional costs increased to achieve LEED certification.

There are numerous sources of funding, financial incentives, regulations and policies for green building available at the national, state, and local levels for homeowners, industry, government organizations and nonprofits. For the City of Portland's example, there are Federal Tax Credits for Energy Efficiency, City of Portland - Green Building Policy and LEED Certification $^{30}$, Renewable Energy Systems Exemption ${ }^{31}$, Direct Financial Subsidy

30 In 2001, the City of Portland adopted a Green Building Policy requiring new construction and major renovations of all city facilities to meet the Certified level of LEED. This policy was amended on April 27, 2005 by Resolution Number 36310, which was adopted by the Portland City Council. At that time, the Green Building Policy was changed to require new buildings to meet the LEED Gold standard. Additionally, the 2005 changes required LEED EBOM Silver for existing buildings. This policy was further amended in April 2009, with the passage of Resolution Number 36700. This resolution includes measures to incorporate the Green Building Policy and green building principles into city operations. Building construction projects and operations and maintenance will be financed at a level appropriate for the implementation of the Green Building Policy. $\mathrm{http}: / /$ www.dsireusa.org/incentives/incentive.cfm?Incentive_Code=OR16R

31 Oregon law states that any change in real market value to property due to the installation of a qualifying renewable energy system is exempt from assessment of the property's value for property tax purposes. Qualifying renewables include solar, geothermal, wind, water, fuel cell or methane gas systems used to heat, cool or generate electricity. This exemption is intended for end users and only applies to systems that are net metered or primarily intended to offset on-site electricity use. Systems installed on real property that is otherwise exempt from property taxation will continue to be exempt. http://www.dsireusa.org/incentives/incentive.cfm?Incentive_Code=OR01F\&State=federal\&currentpage id $=1 \&$ ee $=0 \&$ re $=0$ 
and the Grey to Green Incentive ${ }^{32}$, FAR Bonus $^{33}$, etc. For local government, sitting squarely at the intersection of law, policy, economic development, land use decisions, and the public interest, have a unique opportunity to address sustainability ${ }^{34}$. On one hand, local governments provide incentives and subsidies for encouraging developers to build green buildings, and to deliver environmental and social benefits. On the other hand, they should keep a keen insight into reveal the local real estate market phenomenon as well as identify environmental certification system as an important tool in order to increase popularity of green buildings. In brief, local government should provide a reliable reference for the decision making of the developers and customers.

Since the value of green buildings depends on the definition of green buildings, types of buildings, locations, public policies and user preferences, current empirical studies on green buildings are still limited for making broad policy proposals. More empirical studies for different property types in different areas are necessary to better understand the value of green design and operation.

32 In 2008, Portland Mayor Sam Adams launched the Grey to Green Initiative (G2G). The term "grey to green" refers to expanding the city's green stormwater management infrastructure to protect and improve the efficiency of traditional piped stormwater systems. The G2G Initiative provides funding for green roof outreach and construction. Portland offers $\$ 5 /$ square foot of new green roof. $\mathrm{http}: / /$ www.myplantconnection.com/green-roofs-legislation.php

33 The city of Portland offers a Floor Area Ratio bonus in its building code. Developers may build an extra $3 \mathrm{sq} / \mathrm{ft}$ per foot of green roof they construct without additional permits. They also offer a grant reimbursement of up to $\$ 5 \mathrm{per} \mathrm{sq} / \mathrm{ft}$ for reducing stormwater infrastructure with a green roof. http://www.myplantconnection.com/green-roofs-legislation.php

34 U.S. Green Building Council. (2012). A Local Government Guide to LEED for Neighborhood Development. Available at: http://www.usgbc.org/Docs/Archive/General/Docs6131.pdf 


\section{REFERENCES}

Bartlett, E., \& Howard, N. (January 01, 2000). Informing the decision makers on the cost and value of green building. Building Research and Information, 28, 315-324.

Dermisi, S. V. (January 01, 2009). Effect of LEED Ratings and Levels on Office Property Assessed and Market Values. Journal of Sustainable Real Estate, 1, 1, 23-48.

Eichholtz, P., Kok, N., \& Quigley, J. M. (December, 2010). Doing well by doing good? Green office buildings. American Economic Review, 100, 5, 2492-2509.

Eichholtz, P., Kok, N., \& Quigley, J. M. (October, 2010). Sustainability and the dynamics of green building: New evidence on the financial performance of green office buildings in the USA. Research Report in RICS Research.

Eichholtz, P., Kok, N., Quigley, J. M. (2010). The Economics of Green Building. Available at:

http://cbey.yale.edu/uploads/Environmental\%20Economics\%20Seminar/EKQ\%2 0082010\%20JMQ\%20(2).pdf

Elwell, C. K. (April 18, 2013). Economic recovery: Sustaining U.S. economic growth in a post-crisis economy. Congressional Research Service. http://www.fas.org/sgp/crs/misc/R41332.pdf

Fuerst, F. (January 01, 2009). Building momentum: An analysis of investment trends in LEED and Energy Star-certified properties. Journal of Retail and Leisure Property, 8, 4, 285-297.

Fuerst, F., \& McAllister, P. (January 01, 2011). Eco-labeling in commercial office markets: Do LEED and Energy Star offices obtain multiple premiums?. Ecological Economics, 70, 6, 1220-1230.

Fuerst, F., \& McAllister, P. (2011). Green noise or green value? Measuring the effects of environmental certification on office property values. Real Estate Economics, 39, $1,45-69$.

Fuerst, F., \& McAllister, P. (January 01, 2009). An investigation of the effect of ecoLabeling on office occupancy rates. Journal of Sustainable Real Estate, 1, 1, 4964. 
Fuerst, F., \& McAllister, P. (April 03, 2009). New evidence on the green building rent and price premium. Available at SSRN: http://ssrn.com/abstract $=1372440$ or http://dx.doi.org/10.2139/ssrn.1372440

Kok, N., McGraw, M., \& Quigley, J. M. (May 01, 2011). The diffusion of energy efficiency in building. American Economic Review, 101, 3, 77-82.

Miller, N. G., Pogue, D., Gough, Q. D., \& Davis, S. M. (2009). Green buildings and productivity. Journal of Sustainable Real Estate, 1, 1.

Miller, N. G., Spivey, J., \& Florance, A. (July 12, 2008). Does green pay off?. J. Real Estate Port Man, 385-399.

Nelson, Andrew J. (November, 2007). The Greening of U.S. Investment Real Estate Market Fundamentals, Prospects and Opportunities. RREEF Research, No. 57

Newsham, G. R., Mancini, S., \& Birt, B. J. (August 01, 2009). Do LEED-certified buildings save energy? Yes, but. Energy \& Buildings, 41, 8, 897-905.

Pivo, G., \& Fisher, J. D. (December 01, 2010). Income, value, and returns in socially responsible office properties. Journal of Real Estate Research, 32, 3, 243-270.

Roodman, D. M., \& Lenssen, N. (January 01, 1995). A Building Revolution: How Ecology and Health Concerns Are Transforming Construction. Worldwatch Paper, 124.

Rosen, S. (January 01, 1974). Hedonic Prices and Implicit Markets: Product Differentiation in Pure Competition. Journal of Political Economy, 82, 1, 34-55.

Shimizu, Chihiro. (July 01, 2010). Will green buildings be appropriately valued by the market? Working Report in Reitaku Institute of Political Economics and Social Studies, Reitaku University.

Wiley, J. A., Benefield, J. D., \& Johnson, K. H. (January 01, 2010). Green Design and the Market for Commercial Office Space. The Journal of Real Estate Finance and Economics, 41, 2, 228-243.

Yoshida, Jiro, \& Sugiura, Ayako. (March 01, 2012). Which "Greenness" is Valued? Evidence from Green Condominiums in Tokyo. 46th Annual AREUEA Conference Paper.

Yoshida, Jiro. (May 23, 2008). Technology Shocks and Asset Price Dynamics: The Role of Housing in General Equilibrium. Available at SSRN: http://papers.ssrn.com/sol3/papers.cfm?abstract_id $=1071523+$ 
Yoshida, Jiro and Shimizu, Chihiro. (2010). Impact of Green Buildings on Real Estate

Price: A Case of New Condominiums in Japan. CSIS Discussion Paper. 